\title{
Making sense of the past
}

\section{Colin Renfrew}

A History of Archaeological Thought. By Bruce G. Trigger. Cambridge University Press: 1990. Pp. 500. £37.50, \$59.50.

THE late Glyn Daniel was the first to realize that the really important advances in archaeology were not the great discoveries, the spectacular excavations or the gold of the pharaohs. The real task of archaeology is not the unearthing of relics, although that too has its place, but the undertaking of making sense of the past. This view was already implicit in his $A$ Hundred Years of Archaeology (Duckworth, London, 1950), the first, and until now the only satisfactory history of the subject. It found its most coherent expression in his The Idea of Prehistory (Watts, London, 1962), which remains the most coherent and attractive introduction to archaeology-as-thought rather than archaeology-as-dug.

It is the great merit of Bruce Trigger's $A$ History of Archaeological Thought that it builds on the perception of Daniel that the true history of archaeology is the history of ideas, using and reflecting the great self-awareness in matters of theory and method which came to the subject with the emergence of the 'new archaeology' around the time that the first edition of The Idea of Prehistory was published. Of course the new archaeology ensures that it remains a materialist discipline. But with its inception came what the late David Clarke aptly termed "the loss of innocence", and innocence once lost can never be regained.

Trigger's volume has several merits which establish it without question as the only adequate successor to date to Daniel's A Hundred Years of Archaeology. In the first place, Trigger is well read in the archaeology of Europe as well as of North America. He is well aware that the upsurge of archaeological theory in the United States over the past 25 years does not automatically establish North America as the only place where interesting theoretical developments are taking place, or even the most important. He does not suffer from that intellectual myopia which afflicts in this respect so many of his North American colleagues. This is the first book which sets out to review the theoretical developments of our time in a manner beyond the parochial. Indeed he makes a real effort here - perhaps not entirely successful - to go beyond the confines of the English-speaking world: there is a serious attempt to bring Soviet archaeology into the discussion, as well as that of Japan, Africa, New Zealand and Australia. The work is up-to-date (to 1986 or 1987) and Trigger is exceedingly well read: the bibliography contains more than 1,300 titles.

Not surprisingly, Trigger's new book reflects in large measure the preoccupations of his earlier writings. Gordon Childe is given pride of place among archaeological thinkers, reflecting the interests developed in Trigger's Gordon Childe: Revolutions in Archaeology (Thames and Hudson, 1980). I would certainly not quarrel with that assessment, and the discussion of Childe here (as well as that of Grahame Clark) is particularly satisfying. Less satisfying in my own evaluation is the bias already evident in his Time and Tradition: Essays in Archaeological Interpretation (Edinburgh University Press, 1978), where Trigger contrasted the "nomothetic" tendencies, which he saw as characteristic of the new archaeology, with the "idiographic" approach of the historical tradition.

This dichotomy underlies Trigger's treatment of the archaeological thinking of the past 25 years. He is critical of the constellation of ideas which he identifies by linking the 'positivist' aspects of the new archaeology with what he regards as the 'neo-evolutionism' of US writers in recent years. He does not respond by embracing wholeheartedly the position of the self-proclaimed "post-processual" school which has grown up in opposition to the processual outlook of the new archaeology, for he sees the dangers inherent in the extreme relativist position which they have not been able to avoid. But it is not quite clear what he sees as an appropriate alternative. His approach is clearly a particularist one, but he seems dimly aware that explanation usually entails some elements of generalization. For me this is the weakness in Trigger's position, and it is one which colours his entire approach, making him (in my view) undervalue the originality and the lasting value of the contributions made by Lewis Binford and some of his colleagues. Of course Trigger does not dismiss these his intention is to offer a balanced view, and many of his criticisms are reasonable ones. But generalization gets a bad press in this book, frequently being lumped together with the supposed excesses of 'neo-evolutionist' thought, whose significance for US archaeology he considerably exaggerates. The breadth of Trigger's reading, and the catholicity - pluralism almost - of his position means that this bias does not fatally damage his argument. But as a critique of current positions it is hardly a dispassionate treatment.

More obviously irritating is the curi- ously simplistic historicist treatment of the relationship between recent historical events, such as the dropping of the atom bomb or the Vietnam war, and the archaeological thought of the time. That the Zeitgeist should influence writers and thinkers comes as no surprise, and Trigger's comments on the outlook and social milieu of individuals, such as Sir Arthur Evans, are perhaps reasonable enough. But time and again snap judgements about the spirit of the time are used to 'explain' dominant trends in archaeological thought. For instance (page 289): "The neo-evolutionism that developed in the United States in the 1960s was yet another attempt by anthropologists living in a politically dominant country to 'naturalize" their situation by demonstrating it to be the inevitable outcome of an evolutionary process..."; or (page 323): "While the origin of ideas has no necessary bearing on whether or not they are correct, it is fairly obvious that the high-level evolutionary theories that guided the interpretation of archaeological evidence in the 1970 s reflected a serious and prolonged economic, political and social crisis in which the interests of the dominant middle classes were perceived as deeply threatened." This seems to me pure claptrap. For one who would eschew the generalizing approaches of processual archaeology, Trigger seems remarkably ready to generalize about these highly nebulous linkages. As hypotheses they might be worth investigating (if one could devise a strategy for doing so): as a serious commentary on recent archaeological thought they appear to me of a superficiality which contrasts markedly with the careful and scholarly treatment of the book as a whole. There are many such examples of this politico-philosophical historicism. But the reader (and perhaps the author, in a second edition) can readily discount them. They may be an irritation, but they do not seriously damage what is in most other ways a major and frequently very satisfying contribution to the field.

This is the only good and up-to-date history of archaeology now available, and a worthy successor to those mentioned earlier. The author has succeeded admirably in accomplishing what is almost a world survey, presenting a wide variety of ideas both lucidly and accurately. It is a work which all thinking archaeologists will wish to have on their shelves.

Colin Renfrew is Director of the McDonald Institute for Archaeological Research and Disney Professor of Archaeology in the University of Cambridge, Downing St, Cambridge CB2 $3 D Z$, UK.

- Cambridge University Press has recently published The Archaeology of Human Origins. a collection of the most important and influential papers written by the late Glyn Isaac. Edited by Isaac's wife and collaborator Barbara Isaac, price is $£ 37.50, \$ 59.50$. 